\title{
EXAMINING STUDENTS' NEEDS FOR ENGLISH AS REQUIRED COURSE IN DIPONEGORO UNIVERSITY
}

\author{
Dwi Wulandari \\ Diponegoro University, Semarang \\ dwi_luna@yahoo.com
}

\begin{abstract}
This study is aimed at finding out what students need in taking English as required course, what students want to learn, and how they want to learn. The data were taken from 500 questionnaires distributed to students. The data revealed that most of the students do have positive attitude in learning English, and because of this the students have more chances to take the best of their learning. However, as most of the students also take English because they are required to do so, there are also some factors that may discourage learners' motivation in learning, i.e. materials selection, and teaching methods.

Kajian ini ditujukan untuk mengetahui apa yang diinginkan oleh mahasiswa dalam mengambil mata kuliah MKDU Bahasa Inggris, secara spesifik untuk mengetahui materi apa yang mereka ingin pelajari, dan bagaimana mereka ingin mempelajarinya. Data diambil dari kuesioner yang disebarkan pada 500 mahasiswa. Analisis data menunjukkan bahwa sebagian besar siswa memiliki sikap bahasa yang positif dalam mepelajari Bahasa Inggris, dan oleh karenanya mahasiswa memiliki kesempatan lebih banyak untuk mengambil keuntungan terbesar dari perkuliahan tersebut. Namun demikian, karena sebagian besar mahasiswa mengambil mata kuliah tersebut karena kewajiban, ada beberapa hal yang menyurutkan motivasi mahasiswa, yakni pemilihan materi, dan metode mengajar dosen Bahasa Inggris.
\end{abstract}

Key words: need analysis, English in university setting, language attitude, motivation

\section{INTRODUCTION}

English is one of the required two credit courses that must be taken by all of students at Diponegoro University, regardless of their major, except for students of English Department who not only get English as two credit courses, but also learn English in almost all of their entire classes. Apart from the English department, English is offered as the basic general required course along with Religion Education, Sport, Civics, and Bahasa Indonesia. 
Because of English's status as the basic required course, students may take this course almost without even thinking of the content nor the benefit in taking it. Students usually take this course early at their first or second semester once the course is offered. In many cases, there is a possibility that the students take the course without being asked of what they want to learn, nor they have the chance to consider what they want to learn. Most of the departments also do not have certain concept of what should be learnt by the students nor how the students should learn English. Most of English teachers also do not find the need to adapt their teaching materials with what is needed by the students, either because they are not willing to spend extra time doing need analysis, or because they are overwhelmed already with the many classes they have to handle.

It is necessary, if not yet important, to identify what is needed in achieving the target in learning English. It is necessary to acknowledge why the students need to take the course, to pin point why the learners are willing to spend time to learn it, and to understand how the students want the class to be conducted. When we know what the aims are targeted in taking the course, what are the preferred ways in learning English, and what are considered important in learning, then such information can be very useful for "...setting up the learning objective and goals, setting up positive language learning environment, enhancing learners' motivation, and evaluating their progress in specific ESP skills such as writing and reading" (Rostami \& Zafarghandi, 2014).

Without conducting needs analysis, it will be difficult for the teachers to set learning goals as well as the materials that are suitable for students with various backgrounds and needs. Without needs analysis, we will not know what students expect in learning English, what skills they want to master at, what materials that will support their need in supporting their main competence, and so on (Taillefer, 2007). Likewise, needs analysis is considered a crucial initial step in conducting course design that will be very useful in the subsequent process of language learning (John, 1991). Due to that, it is not surprising that the learning result mostly are disappointing, or at least it is difficult for the teacher to see whether students do improve their English skills, or find the English lesson useful in supporting their main targeted competence or field of study.

It is necessary, therefore, to conduct needs analysis to find the picture of what students need for their English learning. The needs analysis is needed to provide an illustration of what is actually needed by the students, and what the students expect from taking English. Needs analysis may be conducted in various ways, among other things, Present Situation Analysis (Songhori, 2008), in which the needs analyzed are taken from the reflection of the present situation of learning.

This article is aimed at finding the answer for what the learners want in learning, what materials will be helpful for students in improving their field competence, what skills the students need to learn, and how they want to learn them. The needs analysis is focused on how the learners establish such needs after a period of study; hence learners will be able to view their needs by projecting on their experience in learning English.

\section{Needs Analysis in English for Specific Purposes}

English learning setting can be defined in many terms, one of which is English for 
Specific Purposes (ESP). In ESP, as the name suggested, the target in learning is focused on specific aims suited with students' need. For instance, English for tourism is targeted for those who want to learn on how English is used in tourism world, or English for nursing is for those who learn on how English is used in nursing job. Because of those specific reasons or purposes, it is indeed necessary to carry out those reasons in the lesson. In other words, it is necessary to figure out what students' needs in learning English, as noted by Robinson (1991) that learners' need is one of the fundamental concepts that should be taken into account in establishing any ESP courses.

As a course designed supposedly for English for Specific Purposes, English in university setting should base their learning process based on the result of needs analysis. Because by conducting needs analysis prior to the actual teaching learning process, we will be able to know the goal of the learning, what should be learnt, and to what extent those needs to be learnt (Johnson, 2001). The result of the analysis can be very useful to determine the success of the learning for the students, and to ease the teaching process as well, hence the teacher will not be overwhelmed in teaching the class, especially in university setting, in which the class is usually big, and the students' level of English mastery is quite various.

Needs analysis is important in designing syllabi for ESP, because it is necessary that the teachers are able to acknowledge various points, by focusing on the interdisciplinary subjects with the consideration of cultural role, institutions' need, and the main competence of the field study targeted for the students (Lockwood, 2012). By having needs analysis, the syllabi can be composed by incorporating various elements in the form of task-based, text-based, or contentbased by considering the recent development (Flowerdew, 2005).

\section{Learners' Reflection as Need Analysis}

Ideally, needs analysis is conducted prior to the beginning of the class, so that the result can be directly used for determining the materials for teaching and how the teaching is conducted. In many cases, that is how the teachers conduct needs analysis. The most practical one was to set a pre-test for the students, in which the main purpose is to find out how much learners know English, and the information will be used to set where the lessons should start. Richterich and Chancerel as cited by Songhori (2008) mentioned this as one of the examples of Present Situation Analysis.

With Present Situation Analysis, the target is to estimate "what the learners' current skills and what their language use are" (Songhori, 2008). In such analysis, there is also the notion of learning experiences as valuable sources of needs analysis. It is necessary to gain information on what the learners are learning, and how they have learnt it. In this case, it will also serve the function to conduct learners' reflection on their learning, and aim the result to be used for needs analysis of the following students, of course determining that the type of the following class would be typically - or even exactly - the same.

In learners' reflection, learners are expected to see how their own learning; how they think of what they are learning (Dewey, 1993 in Zhu, 2014). Within the perspective of reflection, students are made aware of their learning situation; it is necessary for them to be able to find clue of what helps them in learning; and what 
ways help them to learn better. By having such reflection, learners then are able to decide what they want to learn and how they want to learn it, now that they are able to see the purpose of their study.

\section{RESEARCH METHODS}

This descriptive research is designed to describe the students' needs in learning English as the required course at university. It will describe carefully how they have learnt English and what English skills the students prefer to learn or think that they need them to learn English better. The help the learners have is a better picture of what and how they want the lesson to be delivered, the needs analysis is conducted to the learners who have taken English; hence they will be able to see easily what English materials should be better for them to learn, and how they would prefer the lessons.

The data were taken from the questionnaire given to 500 students of Diponegoro University at all classes, focusing on those who are currently taking English, and/or those who have taken English in the previous semester. The population of the research is all of the students who take English within the academic year of 2013 - 2014 (within two semesters). The reason for choosing those students as the population of this research because it is hoped that they will be able to recount easily what are the materials given in English, as well as how they learned English, as they just finish taking the course.

The population of the students who are currently taking English and who were taking English the previous semester is about 5000 students. $10 \%$ of the population will be taken as the samples of the research, and therefore there will be 500 students targeted to fill out the questionnaire. The samples are considered representative in representing the whole population because the samples are taken from various departments, hence the diversity of students in taking English is also taken into account in choosing the samples. The samples are chosen randomly, by first considering the department the students are at.

Data Collection and Analysis Data were collected through survey method by utilizing questionnaire. This method was taken due to the fact that it was the most feasible method used in collecting data from a large number of respondents. The questionnaire was targeted to find the answer of students' needs in learning English and the learning of English within the two last semesters. The questions in the questionnaire are mostly in the form of close questions in which the questions are provided with various options of answer. Therefore, the answer then can be grouped into certain categories. In addition, there are also open questions in the questionnaire to provide more chances for more personal answers. The questions are focused on students' perception toward their English learning experience, their hopes in taking the course, the difficulties they encounter, and the concept of ideal learning they want. The respondents were given the questionnaire to fill in. They were given explanation on each question before they filled them in, hence each respondent would have the same perception of the question.

Data gained from the close questions were analyzed quantitatively by looking at its percentages, and data from open questions were analyzed qualitatively. The 
analysis was targeted to find a complete picture of how students reflect on their English learning.

\section{FINDINGS AND DISCUSSION}

\section{Description of English teaching practices at university setting}

English is taught for university students as a general basic required course for all of the departments except in English department. As a basic course, English is not only a course that students need to pass, but English is also used as one of the final prerequisites for graduation. At Diponegoro University, students must compile a certificate showing that they have TOEFL score of $400-500$, depending on the score required by the department. Thus, when a student is not yet able to reach the TOEFL score required by his/her department, s/he may not get his/her graduation, even though they have passed all of the requirements required for obtaining his competence.

As a general basic required course, English is offered in the same ways as other general basic required course like a course on religion, or civics. How the class is handled is also similar, in a way that the class is designed for a big class with more than 50 students, mostly at their freshmen year, and taught by English teachers who mostly are already overwhelmed with the many classes to teach. Such a class design is not a design that is not without complained of being ineffective. Not only do the teachers complain of having difficulties in teaching such big classes, but the students also consider that they learn less in English class, that they feel bored because of the material, the teaching methods and the whole situations in class.

\section{The Materials in English Class}

As English is a language skill class, unlike the other general basic class such as Civics, or Religion Course, how the class is handled should also be different. In language skill class, the emphasis is given not only on how to make students understand the material, but it is also targeted on how students can produce the language skills being taught, and thus the activities in class should be relied on the many exercises needed to be practiced by the students. With such goals, it is difficult to teach English if the class is too big, and if the teachers do not have ample time to prepare the materials and to give feedback for the students.

Because of the big number of the students, English course is mostly arranged as parallel classes. Ideally, students in these parallel classes should learn the same materials, however since these classes are also taught by different teachers then the materials are also different. Only very few departments ask the teachers to have similar questions for the mid and final exams. This actually implicitly says that the teachers teaching parallel classes should teach the same material. Even so, students say that the materials for the parallel classes are also different. It shows that there is no coordination in setting up the materials among the teachers. Because a teacher is responsible for teaching a certain class, testing them, and giving their grades solely, he or she does not feel the need in coordinating materials with other teachers, thinking that it is his or her materials that will be tested and thus the students will 
have no difficulties in completing it.

Very often, the teachers have a big authority in handling the class, mostly because the department does not really give neither instruction nor limitation on how the class should be handled. In other words, most departments only require teachers to teach for 14 meetings in a semester but leave the material for the teachers to choose. That is why mostly it is easy for teachers to choose their own materials and design exam questions based on those materials.

Overall, the students learn general English, and not so much of English for specific purposes, because what the students learn are not specified on shaping their English in accordance with their main competence or field of study. The materials are mostly relied on grammar in which the teachers explain the grammar points and ask the students to spend more time doing the grammar exercises. The data reveal that $30 \%$ of the respondents state that they learn more grammar than other skills. The grammar taught is also the repetition of what students have learned earlier in high schools, or even earlier, in a way that the materials are started from the basic ones such as subject - verb agreement, tense and its verb conjugation, or the use of modals. The focus of the lesson is sometimes on the accuracy of the sentence, and that is what makes the class boring and difficult at the same time.

The second most materials taught is reading. 27\% of the respondents mention that they learn more reading in their English class. Some of the readings are suited with their field of study but most of them are the random topics chosen by the teachers. Some teachers give reading materials in accordance with the topics in the students' field of study, for example some teachers give reading on business for students from Economics Faculty, or reading on health issues for Medical students. However, that does not mean that that they are teaching within the frame of English for Specific Purpose, because the students are not learning to use English to work on their field of study's competence. Most of students state that the reading can be interesting but how it is taught sometimes is boring because it is quite monotonous and centered on the teachers.

Students also state that they are taught to write in English. They (22\%) make mention of having writing exercises. The writing exercises however are more like guided sentence writings, in which the students are asked to complete the blank in the sentence with the correct verbs, to rearrange the jumbled sentences, or to provide correct adverb or adjective in sentences, instead of composing a paragraph consisting topic sentence and supporting sentences. In that way, the writing exercises tend to be like grammar exercises because students are not trained to create a good paragraph or utilizing the vocabularies that they've known.

$17 \%$ of students mention that they are also taught to speak in English. The speaking activities are centered on students' presentations on certain topic given by the teacher. In some classes students are asked to present topics on certain grammar points, in some other classes the students are asked to present certain social issues given by the teachers. In this type of activity, students present in group of 5-10 students, therefore each student does not have a good chance to speak in English, and usually only the students who are already good at English are asked to speak more by the other students in their groups. In that way, it is difficult actually for all students to improve their ability to speak in English.

The last material that is taught to the students is the TOEFL material. $4 \%$ of 
the respondents say that the main materials to learn are TOEFL exercises. It is not very clear actually how the material is taught, because TOEFL materials require the teaching of listening as well. With the setting of general big class, it will be difficult for the teacher to teach listening skills, especially since most of the classrooms are not equipped with a sound system and an audio player. However, since TOEFL score also becomes one of the requirements for graduation, some teachers feel the need to teach that subject to the students.

\section{How to conduct the class}

As mentioned earlier, English classes are mostly conducted as parallel classes, and yet the students in a different class within the same parallel classes learn different lessons. In grammar classes, the teachers' explanation is described as grammar translation method, in a way that teachers explain the grammar points in Bahasa Indonesia, focusing on how the sentence structure in English is different from the one in Bahasa Indonesia. In that way, the teachers become the center of the teaching and learning process. In such situation, it is difficult for the students to pay attention closely without losing any concentration. Sometimes the material is just too easy for the students, something that they have known such as Subject - verb agreement, though they admit that they still make mistakes in that point, and therefore they get bored easily.

Students also admit that the teachers also ask the students to work in a group to prepare a presentation, hence this way the students can be the center of the teaching and learning process. Students say that by having group work and presentation assignment, they feel more responsibility in learning, in a way that they are more motivated to do the assignment and at the same time they have the chance to learn the materials. However, sometimes the teachers do not give clear guidelines, or enough prepared materials, hence the students find difficulties in completing the assignment. Most of the presentations are not considered being fruitful as well, because there is the tendency that not all students share the same responsibility in delivering the presentation. Sometimes only the students who are already good at English deliver the whole presentation, hence it is difficult to see whether everyone participates in the assignment or not.

\section{Students' need for English as a required course}

\section{The purpose of taking English}

English course is offered mostly in the freshman year, that is the department usually offers the class either in the first or in the second semester. Because of that most of the students (58\%) take English when it is offered, especially when it is offered in the first semester, because in the first semester students are usually obliged to take the whole courses offered. However, if English is offered in the second semester, there is possibility that students may not take the class as they prefer to take other course suited with their field of study. Thus, $4 \%$ of the respondents take it in the third semester, $1 \%$ in the fourth semester, and another $1 \%$ in the seventh semester. No students take English in the fifth and sixth semesters because in those two semesters students are taking heavier subjects in their field of study such as research method, or seminar. 
Even though some students (29\%) are taking English because it is a required course, some students do have other positive purposes in taking the class. $23 \%$ of the respondents are taking English with the purpose to improve their knowledge in English. This is actually a common purpose, because such purpose is not specifically targeted for gaining particular benefits in taking the class. In fact, it is just a common sense, that if we are doing something we are hoping to get benefit in turn, generally. Only a few students who are able to define the benefit targeted from taking English. Some respondents take English in the hope that they will be able to communicate in English (9\%), to give more credits in their resume for future job (10\%), to use English to make their text book reading easier, and therefore will ease their mastery of knowledge in their field of study (4\%), to use for writing their thesis abstract $(1.5 \%)$, to help them better prepare for graduate study admission $(0.5 \%)$, and to prepare for TOEFL $(3.5 \%)$.

In addition, students also have positive attitude toward English class, which in the end will generate positive motivation in learning English. The positive attitude is related with the status of English as the international language, in the sense that $5.5 \%$ of the students consider that it is important to learn English, that $8.5 \%$ of the respondents see the important function of English as the international language. Some other students $(2.5 \%)$ also mention that mastering English is necessary to help them to work abroad or to get scholarship abroad. Because of this positive attitude for English, they (3\% of the students) like to study English in general, and they like to study English skills in particular such as grammar, listening, or writing. In short, the students' purpose in taking English can be viewed from the following table:

Table 1. Students' purposes in taking English

\begin{tabular}{|l|c|}
\hline To fulfill the requirement to taking basic general course & $29 \%$ \\
\hline To improve the ability in English & $23 \%$ \\
\hline To be able to communicate in English & $9 \%$ \\
\hline To give more credits for the future jobs & $10 \%$ \\
\hline To support the main competence in the field of study & \\
To ease mastery of knowledge in their field of study & $4 \%$ \\
To be able to write thesis's abstract in English & $1.5 \%$ \\
To prepare for TOEFL & $3.5 \%$ \\
To prepare for graduate study admission & $0.5 \%$ \\
\hline To respond to the fact that English is international language & $8.5 \%$ \\
\hline To respond to the fact that it is important to master English & $5.5 \%$ \\
\hline To help them to work abroad or to win scholarship abroad & $2.5 \%$ \\
\hline To express their preference in studying English in general, and & $3 \%$ \\
particular English's skills. & \\
\hline
\end{tabular}

\section{The benefit in learning English}

In general, the benefit in taking English class is analyzed from the data on how the students feel the benefit from taking the English class and on how the class supports their main competence and how the class may help them to achieve their purpose. The main benefit in taking English class asserted by the students is that the class 
does improve their ability in English. $76 \%$ of the respondents emphasize that no matter how the class is conducted, they feel that the class help them improve their English skills.

Likewise, students also consider that taking English class also help them ease their mastery of their main competence, that is the competence targeted in their field of study. $78 \%$ of the students state that even though they do not mention explicitly how English may help them in that way.

In detail, the students mention the following as the reasons that make the students able to take the best advantage of their English class:

Table 2. The reasons enabling the students to take the best advantage of their English class.

\begin{tabular}{|l|l|}
\hline The materials are explained clearly. & $20 \%$ \\
\hline The students are given a chance to be involved actively in the class. & $24 \%$ \\
\hline $\begin{array}{l}\text { The students do not have make a lot of preparation for the class, because } \\
\text { the } \\
\text { teacher will explain almost everything. }\end{array}$ & $7 \%$ \\
\hline $\begin{array}{l}\text { The materials are very interesting, because the teachers use authentic } \\
\text { and new } \\
\text { materials. }\end{array}$ & $10 \%$ \\
\hline The materials enable the students to improve their English. & $24 \%$ \\
\hline $\begin{array}{l}\text { The materials are arranged to support the main competence of their field } \\
\text { study } \\
\text { hence they ease the mastery of the competence. }\end{array}$ & $15 \%$ \\
\hline
\end{tabular}

As can be concluded from the table above, there are three main points in viewing what can make students take the best advantages of their English lesson: their own motivation, teaching methods and materials, and the influence of the teachers. On the first point, students feel that they may get better benefits from the learning if they are aware of the positive impact of having English competence. This awareness will create positive attitude in learning, and in turn will help them to take the best advantages in learning. Thus the students can make use of the materials given by the teachers in making their mastery of their main competence easier. In addition, the students can also utilize the materials to improve their English skills in general.

The second point in making the students easy to take the best advantages from their English class is the teaching methods and materials. Table 2 shows that the students can get the best advantages from their class is when they are allowed to participate actively in the class. In fact, students enjoy to have student-centered learning in learning their lessons, because they can make use of their time and freedom in taking what is important in learning. In this type of method, they also have chances to exercise what they have known and practice more. Actually, the students have already had "some" English because they have learnt English since they were in high school and even earlier, in junior high school or elementary school, though how far they know English could be very different. In fact with this different level of mastery, students appreciate the method better, because for those who are already good at English, they can have self-confidence in showing that, but 
for those who are not so good at English, they can make use the chances for practicing both individually and in group.

The other factor that the students mention in accelerating their learning benefit is the teachers. When the teachers are able to explain the whole material clearly, the students feel that the lesson is a lot easy to understand and the fact that they don't have make a lot of preparation prior to attending the class makes them feel a lot easier with the lessons.

\section{The future idealized English class for the students}

As adult students taking English for their supporting competence, the students indeed are able to define what they want to learn and how they want to learn. They are also able to define their goals in taking the class; what their expectations are. Apart from what has been explained previously, the students also name several things that will discourage them in learning English as follows:

Table 3. Things that will discourage students' motivation in learning

\begin{tabular}{|l|l|}
\hline The teachers explain the material too much. & $7 \%$ \\
\hline The materials are too easy. & $5 \%$ \\
\hline $\begin{array}{l}\text { The materials are just the repetition of the materials they learned in high } \\
\text { school }\end{array}$ & $11 \%$ \\
\hline The materials, especially reading are not interesting. & $6 \%$ \\
\hline The materials are boring. & $11 \%$ \\
\hline The teachers only give assignment without enough explanation. & $5 \%$ \\
\hline $\begin{array}{l}\text { The materials are not related with the competence targeted in their field } \\
\text { of study. }\end{array}$ & $6 \%$ \\
\hline The teachers do not explain the materials well. & $6 \%$ \\
\hline
\end{tabular}

From the table above, we can see that there are two big factors influencing the students' motivation in learning English; teaching materials and the teachers. Students say that when the materials are too easy and are just the repetition of the materials they learnt in high school, they will get bored easily, especially when they feel that they have some ability in practicing their English. Besides, they need to have interesting readings that are related with the main competence targeted in their field of study.

Students assert that if teachers explain the whole materials, then the lessons are no longer interesting. Students need to participate actively instead of just listening to what the teachers say. However, if the teachers only gave assignment without giving time for enough explanation, students also feel reluctant, because the regular meeting will always be filled with one exercise and another exercise, which may not necessarily correlate one another, and more grammar oriented.

\section{CONCLUSION}

To create good environment in learning English, both for the students and the teachers, and to achieve fruitful results, it is necessary to figure out what students want in learning English, and also how they want to learn it. Having such information, the teachers can use it to design the class, to select the appropriate 
materials, and to decide how the class will be conducted, with the purpose of suiting all of those arrangements with what is expected by the students.

The needs analysis studied in this article is focused on students taking English as required course in university setting. There are two main points generated from the study; the fact that the students have positive attitude toward learning English and the goals of being able to master English skills, and that a certain process in learning may discourage their motivation. Being aware that English is international language, and that mastering it for communication will benefit students in so many ways. Having such positive attitude, students are able to take the best of what they learn.

However, there are also other things that need to be considered. As most of the students take English because they have to, and because they do not have any ideas what kinds of materials they will learn, the students tend to be influenced by the materials selection, and how the teachers conduct the class.

\section{REFERENCES}

Flowerdew, Lynne. 2005. Integrating Traditional and Critical Approaches to Syllabus Design: the What, the How, and the Why? Journal of the English for Academic Purposes 4 (2005) 135 - 147.

Johns, A. (1991). English for specific purposes: Its history and contribution. In Celce-Muria M (ed). Teaching English as a Second or Foreign Language. P. 67 - 77. Boston: Heinle \& Heinle.

Johnson, Keith. 2001. An Introduction to Foreign Language Learning and Teaching. New York: Pearson Education.

Lockwood, Jane. 2012. Developing an English for Specific Purpose Curriculum for Asian Call Centres: How Theory can Inform Practice. English for Spesific Purposes 31 (2012) $14-24$.

Robinson, P. (1991). ESP Today: A Practitioner's Guide. New York: Prentice Hall. Rostami, Fatemeh \& Zafarghandi, A. M. 2014. EAP Need Analysis in Iran: The case of University Students in Chemistry Department. Journal of Language Teachinng and Research. Vol 5, No. 4. p. $924-934$.

Songhori, Mehdi H. (2008). Introduction to Need Analysis. English for Specific Purposes World. Vol 4. p. $1-25$.

Taillefer, Gail F. 2007. The Profesional Language Needs of Economic Graduates: Assesment and Perspective in the French Context. English for Spesific Purposes 26 (2007) 135-155.

Zhu, Hongmei (2014). Reflective Thinking on EFL Classroom Discourse. Journal of Language Teaching and Research. Vol 5, No.6 p. 1275 - 1282. 